\title{
Pengaruh Kemampuan Numerik terhadap Hasil Belajar Matematika pada Peserta Didik Kelas VII SMP Negeri 11 Maros Baru
}

\author{
Dedy Setyawan ${ }^{1}$, Arnianti Amir ${ }^{2}$ \\ 1) Program Studi Pendidikan Matematika, FKIP Universitas Muslim Maros \\ ${ }^{2)}$ SMPS PERGIS Maros \\ ${ }^{1)}$ dedy@umma.ac.id \\ 2) arnianti853@gmail.com
}

\begin{abstract}
ABSTRAK
Penelitian ini membahas tentang pengaruh kemampuan numerik terhadap hasil belajar matematika peserta didik kelas VII SMP Negerin 11 Maros Baru. Penelitian ini bertujuan untuk mendapatkan informasi yang berkenaan dengan 1)Kemampuan numerik peserta didik kelas VII SMP Negerin 11 Maros Baru 2)Hasil belajar matematika peserta didik kelas VII SMP Negerin 11 Maros Baru 3) Pengaruh kemampuan numerik terhadap hasil belajar matematika peserta didik kelas VII SMP Negerin 11 Maros Baru. Pendekatan penelitian ini tergolong penelitian kuantitatif dengan jenis penelitian Ex-post facto. Populasi dalam penelitian ini adalah seluruh Siswa Kelas VII SMP Negerin 11 Maros Baru yang berjumlah 133 yang terdiri dari 5 kelas. Sedangkan sampel yang akan diteliti adalah 133 siswa melalui teknik Purposive Sampling. Instrumen yang digunakan dalam penelitian ini adalah tes kemampuan numerik dan dokumentasi hasil belajar matematika. Selanjutnya, teknik analisis yang digunakan adalah teknik analisis statistik deskriptif dan teknik analisis statistik inferensial, dimana untuk menguji hipotesis penelitian menggunakan analisis Regresi Linier Sederhana. Berdasarkan hasil analisis data menggunakan statistik deskriptif, untuk kemampuan numerik diperoleh nilai rata-rata 76,4 berada pada kategori sedang dari 133 sampel diperoleh nilai terendah 57 , nilai tertinggi 96 , dan untuk hasil belajar matematika diperoleh nilai rata-rata 60,13 berada pada kategori rendah dari 133 sampel diperoleh nilai terendah 12 dan nilai tertinggi 92. Adapun hasil analisis statistik inferensial (Regresi Linear Sederhana) diperoleh Sig $<\alpha(0,007<0,05$ Dengan demikian dapat disimpulkn bahwa kemampuan numerik berpengaruh terhadap hasil belajar matematika peserta didik.
\end{abstract}

Kata Kunci: Pengaruh Kemampuan Numerik, Hasil Belajar Matematika

\begin{abstract}
This research discusses the influence of numerical abilities on the mathematics learning outcomes of seventh grade students of the 11 Maros Baru Middle School. This study aims to obtain information relating to 1) Numerical abilities of Grade VII students of SMP Negeri 11 Maros Baru 2) Mathematics learning outcomes of seventh grade students of Central 11 Maros Middle School 3) Effect of numerical ability on mathematics learning outcomes of seventh grade students of junior high school Neginin 11 Maros Baru. This research approach is classified as quantitative research with the type of Ex-post facto research. The population in this study were all Class VII Students of Middle School 11 Maros Baru Middle School, totaling 133 consisting of 5 classes. While the sample to be studied is 133 students through purposive sampling technique. The instrument used in this study is a numerical ability test and documentation of mathematics learning outcomes. Furthermore, the analysis technique used is descriptive statistical analysis techniques and inferential statistical analysis techniques, where to test the research hypothesis using Simple Linear Regression analysis. Based on the results of data analysis using descriptive statistics, for numerical abilities obtained an average value of 76.4 in the medium category from 133 samples obtained the lowest value of 57 , the highest value of 96 , and for mathematics learning outcomes obtained an average value of 60.13 is at the low category of 133 samples
\end{abstract}


obtained the lowest value of 12 and the highest value of 92 . The results of inferential statistical analysis (Simple Linear Regression) were obtained Sig $<\alpha(0.007<0.05)$. Thus, it can be concluded that numerical abilities influence students' mathematics learning outcomes.

Keywords: Effect of Numeric Ability, Mathematics Learning Outcomes.

\section{A. PENDAHULUAN}

Pendidikan merupakan suatu hal yang sangat penting dalam kehidupan manusia. Dengan pendidikan, manusia dapat mengembangkan segala potensi yang ada dalam dirinya. Pendidikan juga bisa diartikan sebagai kegiatan yang dilakukan oleh manusia secara teratur, dengan tujuan untuk mengembangkan potensi yang ada dalam dirinya dan merubah perilakunya ke arah yang lebih baik. Pada pendidikan matematika, sejak peradaban manusia bermula memainkan peranan yang sangat vital dalam kehidupan sehari-hari. Berbagai bentuk simbol, rumus, teorema, dalil, ketetapan, dan konsep digunakan untuk membantu perhitungan, pengukuran, penilaian, peramalan, dan sebagainya.

Matematika sebagai salah satu mata pelajaran yang diajarkan di sekolah merupakan salah satu tolok ukur guna menciptakan SDM yang kompetitif (Jayantika, 2013). Matematika adalah induk ilmu pengetahuan yang dibangun dari pengembangan konsep dasar menjadi bentuk yang lebih kompleks melalui penalaran dan kemampuan menganalisis masalah dengan mengkaitkan masalah pada konsep yang telah diakui kebenarannya (Farah Indrawati). Kegagalan menguasai konsep dasar akan berpengaruh pada penguasaan konsep lanjutan. Dalam pembelajaran matematika dibutuhkan berbagai kemampuan diantaranya, kemampuan numerik, kemampuan penalaran dan sebagainya.

Kemampuan numerik digunakan untuk melakukan perhitungan atau pengoperasian bilangan-bilangan. Pelajaran matematika akan lebih mudah dipelajari oleh orang-orang yang mempunyai kemampuan numerik yang tinggi. Bakat numerik dalam hal ini menyangkut dimensi intelektual siswa yang merupakan suatu kemampuan potensial dalam melakukan operasi hitung secara manual, misalnya operasi penjumlahan, pengurangan, perkalian, pembagian, pemangkatan maupun operasi penarikan akar (Jayantika, 2013).

Dalam mempelajari suatu konsep matematika diperlukan pengetahuan yang akan menjadi landasan berpikir untuk mengembangkan suatu konsep tertentu. Pengetahuan yang dibutuhkan tersebut diantaranya ialah kemampuan numerik yang merupakan kemampuan yang sangat dibutuhkan dalam penyelesaikan soal-soal matematika terutamanya pada soal-soal yang membutuhkan penalaran terlebih dahulu kemudian menerapkannya kedalam rumus dan melakukan perhitungan dengan benar.

Penelitian tentang bakat numerik telah banyak dilakukan oleh para ahli pendidikan. Penelitian yang dilakukan oleh Sogog (1995) menyatakan bahwa secara simultan terdapat 
hubungan yang positif dan signifikan antara kemampuan penalaran, kemampuan verbal dan kemampuan numerik terhadap prestasi belajar matematika siswa. Selaras dengan itu Suratmi (1994) menemukan rendahnya kemampuan numerik siswa merupakan salah satu faktor penyebab kesulitan belajar Matematika. Sehingga bakat numerik merupakan salah satu faktor internal yang mempengaruhi pencapaian prestasi belajar siswa (Jayantika, T 2013).

Permasalahan yang muncul ketika peserta didik tidak dapat mengikuti proses pembelajaran yang dilakukan oleh pendidik karena keterbatasan yang dimiliki oleh peserta didik, misalnya kurang menguasi operasi dasar hitung matematika seperti perkalian, penjumlahan, pengurangan dan pembagian yang dapat menghambat proses pembelajaran yang dilakukan dikelas. (Irawan, 2016)

\section{B. METODOLOGI PENELITIAN}

Metode penelitian yang digunakan adalah metode kausal-komparatif (Expostfacto) yaitu penelitian yang dilakukan setelah kejadian, dalam artian peneliti menyelidiki permasalahan dengan mempelajari atau meninjau variabelvariabel.

Desain penelitian yang digunakan dalam penelitian ini yakni:

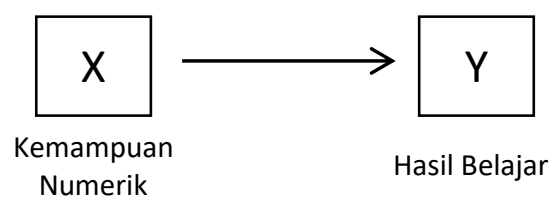

Penelitian dilaksanakan di SMP Negeri 11 Maros Baru yang beralamat di Jl. Pangkasalo,
Kelurahan Baju Bodoa, Kecamatan Maros Baru, Kabupaten Maros. Adapun waktu penelitian dilaksankan pada semester genap tahun pelajaran 2018/2019. Populasi dalam penelitian ini adalah seluruh peserta didik SMP Negeri 11 Maros Baru dan berdasarkan teknik pengambilan sampel purposive sampling maka yang menjadi sampel adalah seluruh kelas VII SMP Negeri 11 Maros Baru sebanyak 133 orang.

Penelitian ini dilaksanakan dengan tiga tahapan yaitu tahap persiapan, tahap pelaksanaan, dan tahap pengolahan data.

\section{Tahap Persiapan}

a. Melakukan observasi ke SMP Negeri 11 Maros Baru yang bertujuan untuk membuktikan kelayakan populasi untuk dijadikan lokasi penelitian.

b. Kemudian menyusun instrument penelitian yang kemudian divalidasi oleh validator

2. Tahap Pelaksanaan
a. Pemberian tes kemampuan numerik
b. Pemberian tes hasil belajar

3. Tahap Pengolahan Data

a. Mengolah dan menganalisis data yang telah diperoleh dari masing-masing sampel penelitian

b. Penarikan kesimpulan dari hasil olah data dan analisis data

Widoyoko (2014:50) mengungkapkan bahwa "instrumen penelitian merupakan alat bantu yang digunakan oleh peneliti untuk mengumpulkan data penelitian dengan cara melakukan pengukuran". Sehingga teknik 
pengumpulan data dalam penelitian ini terbagi menjadi dua bagian yaitu data yang dihasilkan dari serangkaian tes obyektif untuk mengukur tes kemampuan numerik dan hasil belajar peserta didik dimana setiap soalnya memiliki empat alternative jawaban. Kemudian yang kedua adalah data dari dokumentasi yang merupakan data mengenai hal-hal atau variabel yang berupa catatan, transkip, hasil observasi, serta gambaran selama penelitian ini berlangsung.

Tabel 1. Kisi-Kisi Soal Tes Kemampuan Numerik

\begin{tabular}{|c|c|c|c|}
\hline Variabel & Sub Variabel & Indikator & No. Item \\
\hline \multirow{4}{*}{$\begin{array}{l}\text { Kecerdasan } \\
\text { Numerik }\end{array}$} & \multirow{2}{*}{$\begin{array}{l}\text { Kemampuan } \\
\text { untuk relasi } \\
\text { angka }\end{array}$} & $\begin{array}{l}\text { Memiliki pemahaman Pengoperasian (penjumlahan, } \\
\text { penurangan, perkalian dan pembagian) dan sifat-sifat } \\
\text { yang dimilikinya }\end{array}$ & $\begin{array}{l}1,2,3,4 \\
5,6,7,8 \\
9,10,11\end{array}$ \\
\hline & & $\begin{array}{l}\text { Mampu melakukan perhitungan sederhana } \\
\text { matematika }\end{array}$ & 12 \\
\hline & $\begin{array}{l}\text { Kemampuan } \\
\text { terhadap } \\
\text { konsep-konsep } \\
\text { menurut angka }\end{array}$ & $\begin{array}{l}\text { Memahami hubungan antara angka dan kemampuan } \\
\text { untuk melakukan zerhitungan numerik }\end{array}$ & $13,14,15$ \\
\hline & & Jumlah Soal & 15 \\
\hline
\end{tabular}

Berdasarkan pendekatan, jenis dan desain penelitian, data sampel dianalisis dengan menggunakan teknik analisis statistik deskriptif dan teknik analisis statistik inferensial sebagai berikut:

\section{Statistik Deskriptif}

Statistik deskriptif merupakan statistik yang digunakan untuk menganalisis data dengan cara mendeskripsikan atau menggambarkan data yang telah terkumpul sebagaimana adanya dan tidak bermaksud membuat kesimpulan yang berlaku untuk umum atau generalisasi. Nilai yang umumnya dihitung dalam statistika deskriptif untuk mengetahui gambaran hasil belajar peserta didik adalah mean, median, modus, nilai maksimum, nilai minimum, simpangan baku, variansi dan skor Z (skor baku)

\section{Statistik Inferensial}

Statistik inferensial merupakan teknik statistik yang digunakan untuk menganalisis data sampel dan hasilnya diperlukan untuk populasi. Analisis statistik inferensial digunakan untuk rumusan masalah yaitu adakah pengaruh kemampuan numerik terhadap hasil belajar matematika. Statistik inferensial digunakan untuk menguji hipotesis penelitian. Dalam penelitian ini digunakan teknik analisis regresi linier sederhana, karena variabel yang terlibat dalam penelitian ini ada dua, yaitu kemampuan numerik sebagai variabel bebas dan dilambangkan dengan $X$ serta hasil belajar 
matematika siswa sebagai variabel terikat dan dilambangkan dengan $Y$ serta berpangkat satu.

\section{HASIL PENELITIAN}

1. Analisis Statistik Deskriptif

Tabel 2. Statistik Deskriptif

Descriptive Statistics

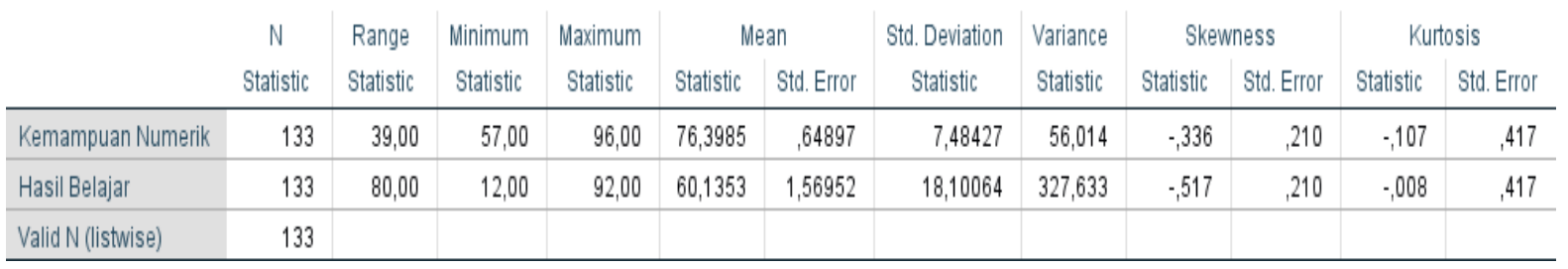

Output tampilan SPSS menunjukkan jumlah responden (N) ada 133 dari 133 nilai peserta didik dari hasil belajar terkecil (Minimum) adalah 12 dan nilai hasil belajar peserta didik terbesar (Maximum) adalah 92, rata-rata dari 133 responden adalah 60,1353 dengan standar deviasi sebesar 18,10064. Tes kemampuan numerik terkecil (Minimum) adalah 57 dan terbesar (Maximum) adalah 96, rata-rata nilai tes kemampuan numerik adalah 76,3985 dan standar deviasi sebesar 7,48427. Rata-rata Kurtosis dan Skewness merupkan ukuran untuk melihat apakah data didistribusikan secara normal atau tidak. Skewness mengukur kemencengan dari data dan Kurtosis mengukur puncak dari distribusi data. Data berdistribusi normal mempunyai nilai skewness dan kurtosis mendekati nol. Hasil tampilan output SPSS memberikan nilai masing-masing hasil belajar Skewness yaitu $-0,517$ dan Kurtosis yaitu -0,008, tes kemampuan numerik masing-masing Skewness yaitu $-0,336$ dan Kurtosis yaitu $-0,107$, sehingga dapat disimpulkan bahwa data tersebut terdistribusi secara normal. Nilai Range merupakan selisih nilai minimum dan maximum. Range hasil belajar yaitu sebesar 80 dan Range kemampuan numerik yaitu 39.

Tabel 3. Kategori Kemampuan Numerik

\begin{tabular}{|c|c|c|c|c|c|c|c|}
\hline \multicolumn{8}{|c|}{ Case Processing Summary } \\
\hline \multicolumn{8}{|c|}{ Cases } \\
\hline & \multirow{2}{*}{ Kategori } & \multicolumn{2}{|c|}{ Valid } & \multicolumn{2}{|c|}{ Missing } & \multicolumn{2}{|c|}{ Total } \\
\hline & & $\mathbf{N}$ & Percent & $\mathbf{N}$ & Percent & $\mathbf{N}$ & Percent \\
\hline \multirow{3}{*}{ Kemampuan Numerik } & Rendah & 19 & $100,0 \%$ & 0 & $0,0 \%$ & 19 & $100,0 \%$ \\
\hline & Sedang & 91 & $100,0 \%$ & 0 & $0,0 \%$ & 91 & $100,0 \%$ \\
\hline & Tinggi & 23 & $100,0 \%$ & 0 & $0,0 \%$ & 23 & $100,0 \%$ \\
\hline
\end{tabular}

Berdasarkan output SPSS diatas untuk kemampuan numerik menunjukkan bahwa kemampuan numerik peserta didik berada dalam kategori sedang. Berdasarkan hasil analisis deskriptifnya, hal ini berarti bahwa ratarata peserta didik kelas VII SMP Negeri 11 Maros 
Baru dari 133 responden dengan rata- rata 76,4 terbagi atas 23 peserta didik berada dalam kategori tinggi, 91 peserta didik berada dalam kategori sedang, dan 19 peserta didik berada dalam kategori rendah.

Tabel 4. Kategori Hasil Belajar

\section{Case Processing Summary}

\begin{tabular}{lcccccccc}
\hline & \multicolumn{8}{c}{ Cases } \\
\hline \multirow{3}{*}{ Kategori } & \multicolumn{2}{c}{ Valid } & \multicolumn{2}{c}{ Missing } & \multicolumn{2}{c}{ Total } \\
\cline { 2 - 9 } & & $\mathbf{N}$ & Percent & N & Percent & N & Percent \\
\hline \multirow{3}{*}{ Hasil Belajar } & Rendah & 95 & $100,0 \%$ & 0 & $0,0 \%$ & 95 & $100,0 \%$ \\
\cline { 2 - 9 } & Sedang & 23 & $100,0 \%$ & 0 & $0,0 \%$ & 23 & $100,0 \%$ \\
\cline { 2 - 9 } & Tinggi & 15 & $100,0 \%$ & 0 & $0,0 \%$ & 15 & $100,0 \%$ \\
\hline
\end{tabular}

Berdasarkn output SPSS diatas untuk tes hasil belajar matematika peserta didik menunjukkan bahwa rata-rata skor yang diperoleh peserta didik berada dalam kategori rendah. Berdasarkan hasil analisis deskriptif menunjukkan bahwa hasil belajar matematika peserta didik kelas VII SMP Negeri 11 Maros
Baru dari 133 responden terdapat 95 peserta didik yang berada dalam kategori rendah, 23 peserta didik yang berada dalam kategori sedang dan 15 peserta didik yang terdapat dalam kategori tinggi.

\section{Uji Normalitas}

Tabel 5. Hasil Analisis Uji Normalitas

\begin{tabular}{llr}
\hline & One-Sample Kolmogorov-Smirnov Test & \\
\hline $\mathrm{N}$ & & Unstandardized Residual \\
\hline Normal Parameters ${ }^{\mathrm{a}, \mathrm{b}}$ & Mean & 133 \\
\hline & Std. Deviation &, 0000000 \\
\hline Most Extreme Differences & Absolute & 17,59970096 \\
\hline & Positive &, 068 \\
\hline & Negative &, 064 \\
\hline Test Statistic & &,- 068 \\
\hline Asymp. Sig. (2-tailed) & &, 068 \\
\hline a. Test distribution is Normal. & &, $200^{\mathrm{c}, \mathrm{d}}$ \\
\hline
\end{tabular}

Berdasarkan uji normalitas dengan kolmogorof-smirnov test diperoleh nilai Test Statistic sebesar 0,068 dan Asymp. Sig. sebesar
0,200 lebih besar dari 0,05 maka dapat disimpulkan bahwa dara terdistribusi normal 


\section{Uji Linearitas}

Tabel 6. Hasil Analisis Uji Linearitas

\begin{tabular}{|c|c|c|c|c|c|c|c|}
\hline \multicolumn{8}{|c|}{ ANOVA Table } \\
\hline & & & $\begin{array}{r}\text { Sum of } \\
\text { Squares }\end{array}$ & df & $\begin{array}{r}\text { Mean } \\
\text { Square }\end{array}$ & $\mathbf{F}$ & Sig. \\
\hline Hasil Belajar & Between & (Combined) & 11439,552 & 32 & 357,486 & 1,124 & 323 \\
\hline$*$ & Groups & Linearity & 2360,633 & 1 & 2360,633 & 7,422 & ,008 \\
\hline Kemampuan & & Deviation & 9078,919 & 31 & 292,868 & 921 & ,591 \\
\hline Numerik & & from Linearit & & & & & \\
\hline \multicolumn{3}{|c|}{ Within Groups } & 31808,012 & 100 & 318,080 & & \\
\hline \multicolumn{3}{|c|}{ Total } & 43247,564 & 132 & & & \\
\hline
\end{tabular}

Berdasarkan hasil analisis diatas diperoleh nilai $\operatorname{Sig}(0,591) \geq \alpha(0,05)$ sehingga Ho diterima. Dengan demikian pengaruh kemampuan numerik terhadap hasil belajar bersifat linear.

\section{Uji Hipotesis}

Untuk melihat apakah koefisien regresi tersebut berpengaruh atau tidak (dalam artian variabel $X$ berpengaruh terhadap variabel $Y$ ) dapat kita lakukan uji hipotesis dengan membandingkan nilai signifikansi (Sig) dengan probabilitas 0,005 .

Ho: Tidak terdapat pengaruh antara kemampuan numerik terhadap hasil belajar peserta didik.
$\mathrm{H}_{1}$ : Ada pengaruh antara kemampuan numerik terhadap hasil belajar peserta didik.

Ketentuan:

- Jika nilai signifikansi (Sig) > 0,05, mengandung arti bahwa ada pengaruh kemampuan numerik terhadap hasil belajar peserta didik.

- Sebaliknya, jika nilai signifikansi $($ Sig $)<0,05$, mengandung arti bahwa tidak ada pengaruh kemampuan numerik terhadap hasil belajar peserta didik.

Tabel 7. Hasil Analisis Signifikansi Kemampuan Numerik terhadap Hasil Belajar

\begin{tabular}{|c|c|c|c|c|c|c|}
\hline \multicolumn{7}{|c|}{ Coefficients $^{\mathrm{a}}$} \\
\hline \multirow[b]{2}{*}{ Model } & & \multicolumn{2}{|c|}{$\begin{array}{r}\text { Unstandardized } \\
\text { Coefficients }\end{array}$} & \multirow{2}{*}{$\begin{array}{r}\begin{array}{r}\text { Standardized } \\
\text { Coefficients }\end{array} \\
\text { Beta }\end{array}$} & \multirow[t]{2}{*}{$\mathbf{T}$} & \multirow[t]{2}{*}{ Sig. } \\
\hline & & B & Std. Error & & & \\
\hline \multirow[t]{2}{*}{1} & (Constant) & 16,967 & 15,771 & & 1,076 & 284 \\
\hline & Kemampuan Numerik & ,565 & ,205 & ,234 & 2,750 & ,007 \\
\hline
\end{tabular}

Berdasarkan output diatas diketahui nilai signifikansi (Sig) sebesar 0,007 <0,05, sehingga dapat disimpulkan bahwa Ho ditolak dan $\mathrm{H} 1$ diterima, yang berarti bahwa "ada pengaruh 
kemampuan numerik terhadap hasil belajar peserta didik".

Pada tabel diatas, terlihat pada Constant $(a)$ adalah 16,967 sedangkan nilai kemampuan numerik $(b)$ adalah 0,565 , sehingga persamaan regresinya dapat ditulis dapat ditulis: $(Y=a+b X$ atau16,967+0,565X)

Koefisien $b$ dinamakan koefisien arah regresi dan menyatakan perubahan rata-rata variabel $Y$ untuk setiap perubahan variabel $X$ sebesar satusatuan. Perubahan ini merupakan pertambahan bila $b$ bertambah positif dan penurunan bila $b$ bertanda negatif. Sehingga dari persamaan tersebut bisa diterjemahkan: a. Konstanta sebesar 16,967 menyatakan bahwa jika tidak ada nilai kemampuan numerik maka nilai hasil belajar sebesar 16,967

b. Koefisien regresi $X$ sebesar 0,565 menyatakan bahwa setiap penambahan 1 nilai kemampuan numerik, maka nilai hasil belajar bertambah sebesar 0,565

Sementara untuk mengetahui seberapa besarnya pengaruh kemampuan numerik terhadap hasil belajar dalam nalisis regresi linear sederhana, kita dapat melihat pada tabel Model Summary:

Tabel 8. Hasil Analisis Nilai Koreksi Kemampuan Numerik terhadap Hasil Belajar

\begin{tabular}{ccccc}
\hline \multicolumn{5}{c}{ Model Summary } \\
\hline Model & R & R Square & Adjusted R Square & Std. Error of the Estimate \\
\hline 1 &, $234^{\mathrm{a}}$ &, 055 &, 047 & 17,66675 \\
\hline
\end{tabular}

a. Predictors: (Constant), Kemampuan Numerik

Berdasarkan tabel model summary diatas, diketahui nilai $\mathrm{R}$ Squere sebesar 0,055, nilai ini mengandung arti bahwa pengaruh kemampuan numerik $(X)$ terhadap hasil belajar peserta didik
$(Y)$ adalah sebesat 5,5\% sedangkan $94,5 \%$ hasil belajar peserta didik dipengaruhi oleh variabel lain yang tidak diteliti dalam penelitian ini.

Tabel 9. Hasil Taraf Signifikansi dari Regresi Kemampuan Numerik terhadap Hasil Belajar

\section{ANOVA $^{\mathrm{a}}$}

\begin{tabular}{clrrrrr}
\hline Model & & Sum of Squares & df & Mean Square & F & Sig. \\
\hline 1 & Regression & 2360,633 & 1 & 2360,633 & 7,563 &, $007^{\text {b }}$ \\
\hline & Residual & 40886,931 & 131 & 312,114 & & \\
\hline & Total & 43247,564 & 132 & & & \\
\hline
\end{tabular}

Pada tabel anova digunakan untuk menetukan taraf signifikansi atau lineritas dari regresi. Hipotesis penelitian:
Ho: Tidak terjadi hubungan linear antara kemampuan numerik terhadap hasil belajar peserta didik. 
$\mathrm{H}_{1}$ : Terjadi hubungan linear antara kemampuan numerik terhadap hasil belajar peserta didik.

Ketentuan:

Jika Sig $<\alpha$, maka Ho ditolak.

Jika Sig > $\alpha$, maka Ho diterima.

Berdasarkan output diatas diperoleh nilai Sig. $(0,007)<\alpha(0,05)$, dengan demikian Ho ditolak. Dengan demikian ada hubungan linear antara kemampuan numerik terhadap hasil belajar peserta didik.

\section{PEMBAHASAN}

\section{Karakteristik Masing-Masing Variabel}

Tujuan penelitian ini diantaranya adalah untuk mendeskripsikan faktor yang mempengaruhi hasil belajar dalam hal ini kemampuan numerik dan hasil belajar itu sendiri. Hasil analisis data sebagaimana dikemukanan sebelumnya menunjukkan bahwa kemampuan numerik peserta didik kelas VII SMP Negeri 11 Maros Baru berada dalam kategori sedang berdasarkan hasil analisis deskriptifnya, hal ini berarti bahwa rata-rata peserta didik kelas VII SMP Negeri 11 Maros Baru dari 133 responden dengan rata-rata 76,3985 dengan nilai maximum 96 dan nilai minimum 57.

Kemudian hasil analisis data untuk tes hasil belajar matematika peserta didik menunjukkan bahwa rata-rata skor yang diperoleh peserta didik berada dalam kategori sedang. Hasil analisis deskriptif menunjukkan bahwa hasil belajar matematika peserta didik kelas VII SMP Negeri 11 Maros Baru menunjukkan bahwa dari
133 responden dengan rata-rata 76,3985 dengan nilai maximum 92 dan nilai minimum 12.

\section{Hasil Analisis Data}

Hasil analisis data dengan menggunakan SPSS Windows 24, pada penelitian ini dilakukan uji hipotesis, namun sebelum dulakukan uji hipotesis maka dahulu terlebih dahulu dilakukan uji prasyarat analisis yaitu uji normalitas dan linearitas suatu sampel. Uji normalitas menggunakan One-Sample Kolmogorov-Smirnov Test dengan nilai signifikansi yang diperoleh. Berdasarkan uji normalitas dengan kormogorovsmirnov test diperoleh nilai KSZ sebesar 0,068 dan Asymp.sig. sebesar 0,200 lebih besar dari 0,05 maka dapat disimpulkan bahwa data berdistribusi normal.

Uji linearitas dilakukan mengetahui apakah data yang diteliti linear atau tidak. Untuk mengetahui bahwa data bersifat linear atau tidak kita perhatikan pada tabel anova.

Ho: Hubungan variabel kemampuan numerik dan hasil belajar bersifat linear.

$\mathrm{H}_{1}$ : Hubungan variabel kemampuan numerik dan hasil belajar tidak bersifat linear.

Ketentuan:

Yang perlu dilihat adalah hasil uji $\mathrm{F}$ untuk baris Deviation from linearity. Jika $\operatorname{Sig}<\alpha$, maka Ho ditolak. Berdasarkan hasil analisis diatas diperoleh nilai Sig $(0,591) \geq \alpha(0,05)$ sehingga Ho diterima. Dengan demikian pengaruh kemampuan numerik terhadap hasil belajar bersifat linear.

Dengan pengujian hipotesis diperoleh berdasarkan tabel model summary diketahui 
bahwa besarnya hubungan antara kemampuan numerik terhadap hasil belajar yang dihitung dengan koefisien korelasi adalah 0,234. Sedangkan kontribusi atau sumbangan secara simultan variabel kemampuan numerik terhadap hasil belajar adalah 5,5\% sedangkan 94,5\% ditentukan oleh variabel lain.

Berdasarkan tabel anova diperoleh nilai Sig. $(0,007)<\alpha(0,05)$, dengan demikian Ho ditolak. Dengan demikian ada hubungan linear antara kemampuan numerik terhadap hasil belajar peserta didik SMP Negeri 11 Maros Baru.

\section{E. PENUTUP}

\section{Kesimpulan}

Berdasarkan hasil analisis statistik inferensial menyimpulkan bahwa terdapat pengaruh kemampuan numerik terhadap hasil belajar matematika pada peserta didik kelas VII SMP Negeri 11 Maros Baru sebesar 5,5\% sedangkan sisanyan sebesar 94,5\% dopengaruhi oleh variabel lain yang tidak dimasukkan dalam penelitian ini.

\section{Saran}

Informasi hasil penelitian ini semoga dapat menjadi masukan bagi pendidik sehingga dapat menghasilkan peserta didik yang tidak hanya memiliki prestasi yang baik tetapi peserta didik yang berkarakter dan bermoral. 3. Hasil penelitian ini dapat menjadi bahan informasi bagi penulis lain atau calon peneliti untuk menulis dan melakukan penelitian selanjutnya yang berhubungan dengan variabel pada penulisan ini demi pengembangan hasil belajar matematika pada masa yang akan datang.

\section{DAFTAR PUSTAKA}

Irawan, A. (2016). Peranan Kemampuan Numerik dan Verbal dalam Berpikir Kritis Matematika pada Tingkat Sekolah Menengah Atas. AdMathEdu | Vol.6 No.2, 122.

Jayantika, I. G. (2013). Kontribusi Bakat Numerik,Kecerdasan Spasial, dan Kecerdasan Logis Matematis terhadap Prestasi Belajar Matematika. e- Journal Program Pascasarjana Universitas Pendidikan Ganesha , 2. Volume 2

Rahmatullah. (2016). Teknik Penyususnan Instrumen Penelitin. Yogyakarta: Pustaka Pelajar

Sogog. (1995). Pengaruh Kemampuan Numerik terhadap Hasil Belajar Matematika Materi Pokok Dimensi.Tiga.Semarang Fakultas Tarbiyah Institut Agama Islam Negeri Walisongo

Suratmi, (1994). Faktor-Faktor yang Mempengaruhi Kesulitan Belajar Matematika. Bandung: alfabeta

Widoyoko, Eko Putro. (2014). Teknik Penyusunan Instrumen Penelitian. Yogyakarta: Pustaka Pelajar. 